\title{
Balloon Dilation
}

National Cancer Institute

\section{Source}

National Cancer Institute. Balloon Dilation. NCI Thesaurus. Code C113728.

An endoscopic therapeutic procedure in which a balloon device is used to dilate a narrowed lumen. 